\title{
The Whiteness of Ireland Under and After the Union
}

\author{
G. K. Peatling
}

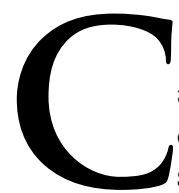

ategories of "race" are flexible and constructed, by no means solely determined by genetics, biology, or skin color. "Races" are thus constructs of the human intellect, and these acts of construction, or racialization, are subjects for legitimate academic interrogation. Racism certainly cannot be reduced to chromatism or prejudice based on skin color, and the recovery of processes of racialization is a research program of relevance to, and of increasing popularity within, the field of Irish studies. ${ }^{2}$ Some researchers, however, have gone further and emphasized the fact and power of circumlocutions adopted by British cultural agencies to justify assumptions that the Irish were (or are) uncivilized in spite of their lacking clear signifiers of racial otherness. For certain scholars, the inferior position of the Irish in Britain within racial hierarchies explains their long-continued invisibility or lowly status, among other features of BritishIrish history. These scholars often imply that it is either accurate or politically productive to draw substantive connections between the positions of the Irish and those of racialized nonwhite groups during phases of colonialism.

After surveying some examples of this literature, this article will suggest serious historical and critical flaws in some common and often politically potent recent interpretations. First, there are those political teleologies that imply that to emphasize or exaggerate historical and contemporary verisimilitudes between the Irish and racialized nonwhite groups is to advance a politically progressive agenda. These can be faulted on both historical and theoretical grounds, in that they trivialize or misinterpret the plight of nonwhite victims of imperialism or subjugation, iron-

G. K. Peatling is a postdoctoral fellow at the University of Guelph (Ontario, Canada). He is the author of British Opinion and Irish Self-Government, 1865-1925 (2001) and of a number of articles on the history of British-Irish relations. His current research interests include Ulster-Scots identity in history.

${ }^{1}$ Kenan Malik, The Meaning of Race: Race, History and Culture in Western Society (Basingstoke, 1996), pp. 1-8; Colette Guillaumin, Racism, Sexism, Power and Ideology (London, 1995), pp. 99-107.

${ }^{2}$ See esp. Bronwen Walter, Outsiders Inside: Whiteness, Place and Irish Women (London, 2001); Noel Ignatiev, How the Irish Became White (New York, 1995).

Journal of British Studies 44 (January 2005): 115-133

(C) 2005 by The North American Conference on British Studies.

All rights reserved. 0021-9371/2005/4401-0005\$10.00 
ically overstate the beneficence of the British political elite, can be inimical to wider progressive coalitions, and may even understate the culpability of individuals from certain political locations in racism. Second, historical research that posits connections and equivalences between the experiences of the Irish and nonwhite groups, often under the influence of Perry Curtis's foundational scholarship, can unconsciously reenact partisan and unsatisfactory positions in British-Irish political debates of the late nineteenth and early twentieth centuries. Third, moments can be located in debates on Irish self-government, particularly discussions surrounding Erskine Childers's The Framework of Home Rule (first published in 1911), that involved clear acknowledgments in Britain of the whiteness of the Irish, and of their distance from nonwhite groups in racial and imperial hierarchies. Since these acknowledgments can be said to have been, in the long run, more politically significant than any countervailing tendencies, I will argue that while study of the racialization of groups and individuals in and from Ireland is certainly pertinent, it is a major distortion to emphasize moments of the equivalence of the positions in racialized hierarchies of the Irish and nonwhite groups.

Few scholars would endorse the view articulated in Roddy Doyle's The Commitments that the Irish are "the niggers of Europe." Nonetheless, such a proposition is considered a suggestive and appropriate starting point for a number of different strands in the application of the concept of racialization to Irish studies. ${ }^{3}$ Racialization itself is potentially a subtle concept, admitting numerous distinctions and capable of suggesting valuable lines of approach to moments in Irish history and aspects of Irish studies. But one important and increasingly influential approach has been to consider the extent to which it is possible to equate the racialization and experience of racialization of "the Irish" (usually meaning the Catholic and/ or nationalist Irish) to that of nonwhite groups. One such direction explores antiIrish racism as an aspect of a "multiracist" British society. ${ }^{4}$ Instancing Frederick Engels's famous description of the Irish in Manchester, ${ }^{5}$ Philip Cohen suggests that the significance of the Irish lies in what they "unconsciously represent in and by the code of breeding" in "English race thinking": the Irish encapsulated all "the British ruling class most feared" by representing "a missing evolutionary link

\footnotetext{
${ }^{3}$ Roddy Doyle, The Commitments (1988; London, 1998), p. 9; Bill Rolston, “Are the Irish Black?” Race and Class 41, nos. 1-2 (July-December 1999): 95-102, esp. 95; Brian Dooley, Black and Green: The Fight for Civil Rights in Northern Ireland and Black America (London, 1998), p. 6; Luke Gibbons, "The Global Cure? History, Therapy and the Celtic Tiger," in Reinventing Ireland: Culture, Society and the Global Economy, ed. Peadar Kirby, Luke Gibbons, and Michael Cronin (London, 2002), pp. 89-106, esp. p. 92. Also see Terry Eagleton, Saints and Scholars (London, 1990), p. 126, where Eagleton has James Connolly say, "Perhaps our skins should have been black, then the British might have known what they were dealing with."

${ }^{4}$ Panikos Panayi, ed., The Impact of Immigration: A Documentary History of the Effects and Experiences of Immigrants in Britain since 1945 (Manchester, 1999), pp. 129-30, 146-50; Mary Hickman, "Alternative Historiographies of the Irish in Britain: A Critique of the Segregation/Assimilation Model," in The Irish in Victorian Britain: The Local Dimension, ed. Roger Swift and Sheridan Gilley (Dublin, 1999), pp. 236-53.

${ }^{5}$ Frederick Engels, The Condition of the Working-Class in England in 1844, trans. Florence Kelley Wischnewetzky (London, 1892), pp. 90-94.
} 
between the 'bestiality' of Black slaves and that of the English worker as well as dangerous currents in European thought, including republicanism." Others see the Irish as a fighting arm of a subaltern "black" struggle within British society. The process by which the whiteness of the Irish was earlier reconciled with their incorporation into a lowly position in British imperial racial hierarchies intrigues many scholars. David Lloyd argues that in cases of racism so lacking clear signifiers of otherness "the fantasmatic projection of differences appears as a wishful representation of disturbance in the visual field." ${ }^{8}$ Claire Wills and Anne McClintock highlight the existence of other demarcations of barbarism in British representations of the Irish. ${ }^{9}$ While Luke Gibbons admits that "the analogy with the oppression of black people cannot be fully sustained," he locates a "model of racism" that offers elucidation of the Irish case in the treatment of "native Americans, or American Indians, an analogy, moreover, which had a foundation in the shared historical experience of being at the receiving end of the first systematic wave of colonial expansion." 10

Scholars of the racialization of the Irish have, however, observed some historical limits to the identification of situations of the Catholic or "native" Irish with those of nonwhites. Mary Hickman and Bronwen Walter's notable report for the Commission for Racial Equality on discrimination and the Irish community in Britain, rather than strictly identifying anti-Irish with antiblack racism, outlines a project of "deconstructing" the idea of "whiteness" as a homogeneous formation. ${ }^{11}$ Bill Rolston identifies the historical participation of Irish individuals in racism and imperialism. Rolston nonetheless endorses the position of Carol Coulter, arguing that irrespective of the proportion of historical experience that features the Irish as victims of racism and imperialism, it is progressive (and perhaps politically desirable) to emphasize such narratives. Coulter thus writes, "Far from being ashamed of our colonial past, we should be happy to acknowledge and even embrace Ireland's status as a post-colonial society. . . . This is a far more exciting club to want to belong to than the complacent and paralyzed world of the former co-

${ }^{6}$ Philip Cohen, "The Perversions of Inheritance: Studies in the Making of Multi-racist Britain," in Multi-Racist Britain, ed. Philip Cohen and Harwant S. Bains (Basingstoke, 1988), pp. 9-118, esp. p. 74.

${ }^{7}$ Ambalavaner Sivanandan, "Challenging Racism: Strategies for the 80s," Race and Class 25, no. 2 (Autumn 1983): 1-11, esp. 4.

${ }^{8}$ David Lloyd, "Race and Representation," Oxford Literary Review 13 (1991): 62-94, esp. 76, 77. In his criticism of this passage, Stephen Howe is possibly unfair in accusing Lloyd of "ascribing to the English the view that in the natural order of things the Irish, as colonial subjects, should be black." Lloyd suggests that the "impossible, catachrestic conjunction . . ' if only they were black . . . . . . persists as an anomaly in English racist discourse," but he does not specifically ascribe this view to "the English" en masse. See Stephen Howe, Ireland and Empire: Colonial Legacies in Irish History and Culture (Oxford, 2000), p. 129.

${ }^{9}$ Anne McClintock, Imperial Leather: Race, Gender and Sexuality in the Colonial Contest (New York, 1995), esp. pp. 52-53; Claire Wills, "Language, Politics, Narrative, Political Violence," Oxford Literary Review 13 (1991): 21-60, esp. 21-22, 56, 56, n. 14.

${ }^{10}$ Luke Gibbons, "Race against Time: Racial Discourse and Irish History," Oxford Literary Review 13 (1991): 95-117, esp. 97, 95-96.

${ }^{11}$ Mary J. Hickman and Bronwen Walter, Discrimination and the Irish Community in Britain: A Report of Research Undertaken for the Commission for Racial Equality (London, 1997), p. 11; Bronwen Walter, "Challenging the Black/White Binary: The Need for an Irish Category in the 2001 Census," Patterns of Prejudice 32 (1998): 73-86. 
lonialist, and present-day imperialist, powers." ${ }^{12}$ Coulter's position is endorsed by Luke Gibbons in advancing the corollary that if "suffering bound up with historical injustice" in the Irish people's "own" past is to be denied-behind which "normalising' narratives" he detects the hand of "revisionist" historians- "there is little likelihood that they will be able to relate to those [refugees and asylum seekers] who come to the Ireland of the Celtic Tiger reminding them of their own unrequited pasts." 13

If some of the authors previously mentioned could be accused of blindness about antiblack racism in Ireland in historical or contemporary settings, this is hardly an allegation that one could apply to Robbie McVeigh. ${ }^{14}$ Nonetheless, McVeigh agrees that it is desirable to emphasize commonalities of experience between the Irish and nonwhite groups, such as a shared past of colonization, since such a process of identification is likely to nourish the most valuable political reaction to the racism of white individuals in Ireland: "Irish people's experience of many of the most terrible consequences of colonialism - genocide, slavery, starvation-have predisposed them to identify with other survivors of colonialism. Their own experience of anti-Irish racism means that there is an affinity with people who experience other racisms. It encourages people to engage with racism in terms of solidarity rather than guilt." ${ }^{15}$ Equivalences highlighted between experiences of the Irish and those of nonwhite groups can also, if unconsciously, carry more obviously tendentious political implications. Connections drawn between Northern Ireland before 1972 and the American South in the civil rights era or apartheid South Africa continue to have a significant power politically to delegitimize the claims of unionists in Northern Ireland. ${ }^{16}$ This is particularly evident in cases where observers are prepared to assume that the demands of Sinn Féin are little more than an elaboration of the claims of Catholics in Northern Ireland for "civil rights."

Across a range of academic and historical perspectives, there is thus an assumption that to recover discourses and practices in which the Irish have historically been placed in a position in racial hierarchies close to that of colonized and subjugated nonwhite groups is not only to locate conjunctures of historical significance but also to heighten the possibility of politically progressive outcomes in the future.

\footnotetext{
${ }^{12}$ Carol Coulter, Ireland: Between the First and the Third Worlds (Dublin, 1990), pp. 9, 22, quoted in Rolston, "Are the Irish Black?" p. 99.

${ }^{13}$ Gibbons, "The Global Cure?" esp. pp. 105, 91, 105; Paul Cullen, Refugees and Asylum-Seekers in Ireland (Cork, 2000), pp. 7, 60; David Lloyd, Ireland after History (Notre Dame, Ind., 1999), p. 105.

${ }^{14}$ Robbie McVeigh, “'There's No Racism because There's No Black People Here': Racism and Antiracism in Northern Ireland," in Divided Society: Ethnic Minorities and Racism in Northern Ireland, ed. Paul Hainsworth (London, 1998), pp. 11-32, and "Is Sectarianism Racism? Theorising the Racism/ Sectarianism Interface," in Rethinking Northern Ireland: Culture, Ideology and Colonialism, ed. David Miller (London, 1998), pp. 179-94.

${ }^{15}$ Robbie McVeigh, The Racialization of Irishness: Racism and Anti-racism in Ireland (Belfast, 1996), p. 40, and "The Last Conquest of Ireland? British Academics in Irish Universities," Race and Class 37, no. 1 (July-September 1995): 109-22, esp. 113, 116-17.

${ }^{16}$ John McGarry, "Introduction: The Comparable Northern Ireland," in Northern Ireland and the Divided World: The Northern Ireland Conflict and the Good Friday Agreement in Comparative Perspective, ed. John McGarry (Oxford, 2001), pp. 1-33, esp. pp. 3-14.

${ }^{17}$ Brian Dooley, Black and Green, p. 132. Compare Andrew J. Wilson, Irish-America and the Ulster Conflict, 1968-1995 (Washington, D.C., 1995), pp. 31-40.
} 
This political intention should not be ascribed to all the scholars who foreground such discourses and practices, but it is admitted by some. Objection may be raised on the grounds that it should be the function of scholars to determine which hypothesis best matches the available data, rather than to decide which data set politically merits most attention. However, it is naive to assume that even scholars who avow the former intention do not have political agendas. In the present case, it may more seriously be contended that certain scholars fail accurately to assess the political beneficence of different historical narratives and thus may actually do more harm than good when recommending a narrative for salient cultural attention. A number of theoretical and historical bases can indeed be advanced for suggesting that to occlude differences between the experiences and representations of the groups in question may not have the anticipated politically progressive consequences.

First, assertions that a white subject "shares" the plight of an oppressed nonwhite Other can constitute an arrogant attempt to monopolize sympathy and speak for the Other. The fact that Gerry Adams claimed that "Irish republicans" felt "a natural, instinctive, and deep affinity with the oppressed black majority in South Africa" raises the question whether this process may also nourish rationalizations of incursions across popularly accepted ethical frontiers. ${ }^{18}$ Admittedly, in such processes of identification a fine line may separate these errors from the production of an effective radical coalition, but this boundary appears to be crossed when nonarbitrary (if problematic) distinctions between the situations of self and Other are occluded. ${ }^{19}$ While extreme cases of imposture as a victim are rare within academia, there are moments at which even subtle scholars in the field evince an anxiety to regard "the Irish" en masse (sometimes including themselves) as oppressed, impoverished, or forcibly transplanted..$^{20}$ In closely connected moments, exaggeration of the historical role of negative racializations of the Irish can also actually entail misrepresentation or trivialization of the plight of nonwhite groups. Perry Curtis, for instance, recently argued that such racialization might help "to explain why Ireland - in the words of one perceptive English historian-was 'the great failure . . . the one irreparable disaster' of English history." ${ }^{21}$ Curtis here accepts self-congratulatory "whiggish" myths about English/British history in an attempt to demonstrate the exceptionalism of Irish historical experience. The idea that English history includes no "great failures" except Ireland could be endorsed only if large swaths of British imperial history outside of Europe (at the very least) are ignored. Similarly, assertions that unionists or the Union embodies the most reactionary or unreconstructed elements of British imperialism comprise a limited view of the depths attained by British imperialism in other contexts and thus constitute a trivialization of the plight of its victims in such contexts. ${ }^{22}$

It is not just British imperial history, however, that is ignored in such perspectives. A second limitation to the progressive implications of emphasizing prox-

\footnotetext{
${ }^{18}$ Gerry Adams, Before the Dawn: An Autobiography (New York, 1996), pp. 278-79.

${ }^{19}$ Dominick LaCapra, Writing History, Writing Trauma (Baltimore, 2001), pp. 25, 27, 28.

${ }^{20}$ Lloyd, Ireland after History, p. 106.

${ }^{21}$ L. Perry Curtis, Jr., Apes and Angels: The Irishman in Victorian Caricature (1971; rev. ed., Washington, D.C., 1996), p. 147. The "perceptive" historian in question was G. M. Young.

${ }_{22}$ Carol Coulter, "Feminism and Nationalism in Ireland," in Rethinking Northern Ireland, pp. 160-78, esp. p. 164.
} 
imities between the Irish and oppressed nonwhite groups lies in the implicit denial of wider connections incorporating other historical subjects, including certain white Europeans. Scholars such as Ned Lebow argue that the different treatment of public order issues in different parts of the United Kingdom shows that the Irish were not regarded as coequal with the British within the nineteenth-century Union: "Outrage in England was not met with arms bills, suspension of civil liberties and the declaration of martial law; the British people would not stand for it." ${ }^{23}$ This constitutes another endorsement of whiggish myths of the beneficence of the British ruling classes, since it seems unsatisfactory to suggest that Luddism, the Captain Swing riots of 1830, or the Scottish Jacobins (to name but three examples) were (in Lloyd's words) "put down within the purview of longstanding legal interventions." ${ }^{24}$ This is not to deny that the nineteenth-century British state's repressive apparatus was often significantly more coercive in Ireland than in Britain, ${ }^{25}$ but the difference can be exaggerated. In any case, that extensive measures of repression were adopted by the independent Irish Free State in its early years demonstrates that coercion in Ireland cannot easily be proved to have been solely derivative of British racialization of the Irish. ${ }^{26}$ Michael de Nie and Hazel Waters argue that centuries of rule of Ireland had produced in "English minds, a widespread, pervasive stereotype of the Irish as a race apart, inferior in every way to the powerful Anglo Saxon" and that this emerged as "fully-fledged" racism in Britain in response to the famine of the $1840 \mathrm{~s} .{ }^{27}$ It is, however, highly debatable whether reading the Great Famine as a moment in the often ambivalent process of racialization is to identify its most significant (and terrifying) historical reality. ${ }^{28}$ More importantly, however, to emphasize racialization in this form as an element of British reactions during the famine is to understate aspects of those reactions that indicate the pertinence of broader progressive political responses. Other scholars have illustrated the extent to which the inadequate response of administrators, particularly in the later years of the famine, was framed within laissez-faire providentialist thinking. According to an influential variant of this ideology, in the words of one historian, "gratuitous food aid perpetuated the very culture of dependency that impeded the full realisation of Ireland's latent human and material resources." ${ }^{29}$ In this view, to intervene, even from well-intentioned humanitarian motivations, would thus have been to compromise the imperatives to beneficent structural reform implicit in the operation of demographic and market forces that

\footnotetext{
${ }^{23}$ Richard Ned Lebow, White Britain and Black Ireland: The Influence of Stereotypes on Colonial Policy (Philadelphia, 1976), p. 67.

${ }^{24}$ Lloyd, Ireland after History, pp. 15-16.

${ }^{25}$ Stanley H. Palmer, Police and Protest in England and Ireland, 1780-1850 (Cambridge, 1988).

${ }^{26}$ Colm Campbell, Emergency Law in Ireland, 1918-1925 (Oxford, 1994).

${ }^{27}$ Hazel Waters, "The Great Famine and the Rise of Anti-Irish Racism," Race and Class 37, no. 1 (July-September 1995): 95-108, esp. 95, 98; Michael de Nie, "The Famine, Irish Identity and the British Press," Irish Studies Review 6 (1998): 27-35, esp. 34.

${ }^{28}$ Avtar Brah, Cartographies of Diaspora: Contesting Identities (London, 1996), p. 15.

${ }^{29}$ Peter Gray, "National Humiliation and the Great Hunger: Fast and Famine in 1847," Irish Historical Studies 32, no. 126 (November 2000): 193-216, esp. 208. See also Christine Kinealy, "Potatoes, Providence and Philanthropy: The Role of Private Charity during the Irish Famine," in The Meaning of the Famine, ed. Patrick O'Sullivan (London, 1997), pp. 140-71; Peter Gray, Famine, Land and Politics: British Government and Irish Society, 1843-1850(Dublin, 1999), esp. pp. 331-32; Christine Kinealy, The Great Irish Famine: Impact, Ideology and Rebellion (Houndmills, 2002), esp. pp. 31-60.
} 
was the famine. In other words, victims of the famine were victims of laissez-faire ideologies, as were and are oppressed or displaced nonwhite groups and (to an admittedly less extreme degree), among others, white British communities and individuals uprooted owing to agricultural enclosure and industrialization or, more recently, deindustrialization, unemployment, and neoliberal economic policies. The experiences of such subjects affected by laissez-faire policies certainly varied widely. Nonetheless, the evangelical movement that influenced Thomas Chalmers and especially Charles Trevelyan, assistant secretary to the Treasury during the Irish famine and often cited in denunciations of British policy, hardly nourished attitudes to the English and Scottish poor sufficiently sympathetic to justify depictions of a sharp, racialized dichotomy in views of the lower classes in Britain and Ireland. ${ }^{30}$ So considered, the famine and its legacy reveal a possibility of "connection," mutual sympathy, and radical coalition between wider and more numerous groups than the perspective of anti-Irish racism and histories of equivalences between the Irish and nonwhite groups can suggest.

Third, it can be argued that to overstate similarities between the historic and contemporary conditions of the Irish and those of victimized nonwhite groups is to inhere a politically unwise naïveté about the complexity of instruments of human oppression. The African-American activist Frederick Douglass is, for instance, sometimes cited as a supporter of the proposition that the conditions of the Irish in Ireland and of slaves in the American South in the mid-nineteenth century were comparable. ${ }^{31}$ Some recent work on Douglass suggests, however, that Douglass was aware of differences between the difficulties of Irish and African-American groups and individuals. Indeed, for Douglass, to differentiate was in some ways more valuable than to detect affinities, since the former demonstrated "that oppression could permeate a population regardless of its race, nationality, or culture." Thus, by combining awarenesses of the variety of forces used to oppress and disempower human beings, more of these forces could be addressed. ${ }^{32}$ Slavery and the famine were not the same, and it helped the victims of neither to suggest that they were. Douglass was indeed aware that to raise the condition of the Irish in the same breath as that of African-American slaves could serve racist interests, by detracting from the power of the case for emancipation. ${ }^{33}$ Indeed, it remains the case that exaggerating the similarities of the histories and experiences of groups of Irish and of African descent, rather than producing a coalition for emancipatory policies, can produce competition for the same scarce cultural resources and attention. $^{34}$

Finally, and perhaps most crucially, proximities drawn between the Irish and nonwhites overlook differences within as much as between those groups, as well as possibilities of radical action by individuals, both from within and from outside of such an alliance, that might depend on other connections and interactions. Any

\footnotetext{
${ }^{30}$ Boyd Hilton, The Age of Atonement: The Influence of Evangelicalism on Social and Economic Thought, 1795-1865 (Oxford, 1988), pp. 69-70, 108-14.

${ }^{31}$ Lloyd, Ireland after History, p. 109, n. 11; Dooley, Black and Green, pp. 1, 14-17.

${ }^{32}$ Patricia Ferreira, "All but 'A Black Skin and Wooly Hair': Frederick Douglass's Witness of the Irish Famine," American Studies International 37, no. 2 (June 1999): 69-83, esp. 81.

${ }^{33}$ Ibid., pp. 80-81.

${ }^{34}$ Matthew Frye Jacobson, Whiteness of a Different Color: European Immigrants and the Alchemy of Race (Cambridge, Mass., 1998), pp. 274-80.
} 
suggestion that the Irish can better identify with impoverished, oppressed, or colonized groups through understanding of their own past as victims presupposes that Irish individuals currently alive possess and can immediately relate to a past of colonization and deprivation. This involves not only a practically essentialist notion of organic links between Irish individuals and experiences of "the Irish" as a group many generations ago but also the idea that such individuals can further connect through such links to other groups, who are also therefore defined in an essentialist fashion. While historical legacies do affect the social condition and selfperception of many Irish (and non-Irish) individuals currently alive, those individuals undergo a variegated set of social experiences and thus relate to and are affected by such legacies in very different ways. The idea that a particular narrative of ethnohistory is "our" (or "their") past, and therefore the appropriate path through which to connect (or differentiate) ethnic groups, by enshrining particular constructions of ethnic groups as necessary foci of such social and intellectual interactions, implicitly devalues narratives of oppression in Ireland arising on other grounds, such as gender. Further, if it is posited that Irish individuals will best relate to other ethnic groups through such modes of essentialism, the possibility of radical commitment by individuals from different ethnic collectivities (which are also presumably to be defined in an essentialist fashion) that did not undergo oppression and colonization as a group is denied, possibly leaving those individuals with no ideological alternative to racism. In a sense, this is to excuse individuals in the "complacent and paralyzed . . . former colonialist, and present-day imperialist, powers" from any moral responsibility for racism. Only an analysis critical of constructs such as "the Irish," "nonwhites," "blacks," and "colonialism" (to name but a few) can consistently acknowledge the fruitful and extensive additional possibilities of progressive political action that are not dependent on such essentialist conceptions but rather subsist on histories of class, gender, region, or (as indicated above) economic and social dislocation.

Is it, however, in any case a legitimate procedure to foreground equivalences or proximities between historical experiences and representations of the Irish and those of colonized or subjugated nonwhite groups? While the fruitful concept of racialization may certainly be applied to this subject in other ways, the frequency of association between the advancement of the proposition that anti-Irish prejudice has exerted a large influence on British-Irish history and the articulation of nationalist political objectives at least justifies a close inspection of the connections between key examples of modern historiographical and "critical" work on the racialization of the Irish and certain partisan positions in earlier political debates.

E. L. Godkin's writings in the early 1880s, including his 1882 article "An American View of Ireland," appearing in the highbrow British periodical the Nineteenth Century, should be regarded by analysts of British prejudice against the Irish as significant. Godkin advocated home rule for Ireland, and he emphasized the political significance of British anti-Irish prejudice at a time when few other than Irish nationalists were putting these ideas before British audiences. Such ideas were shortly, however, to gain a significant currency in Britain and elsewhere, a transition in which Godkin's work must have played a small role. Godkin, the 
Irish-born Anglophile American editor of the New York Nation, maintained that "English dislike of Ireland and Irishmen" was a "fundamental" aspect of political difficulties in Ireland and was an "all but insurmountable obstacle to Ireland's sharing in English national life." ${ }^{35}$ Some aspects of the response to Godkin's article have a striking resonance with more recent historiographical debate. The Spectator quickly took Godkin to task for his argument's alleged heavy use of the evidence of Punch's illustrations, suggesting that Punch's least flattering caricatures of Irishmen did not fairly reflect views in Britain as a whole. ${ }^{36}$ The relevance of Punch caricatures to anti-Irish racism is now much debated in the light of Perry Curtis's Apes and Angels (recently reprinted in a new edition). ${ }^{37}$ In another response to Godkin's essay, Goldwin Smith-an initial object of Godkin's criticism $^{38}$ - contended that Godkin's was actually not "the view . . . of a native American $[s i c]$, but of an Irish Nationalist, animated by the usual feelings of his party towards Great Britain and the Union." 39 This charge and its subsequent denial have been closely replicated in a debate between Perry Curtis and Alan O'Day. ${ }^{40}$

Curtis's explorations of the racialization of the Irish continue to be widely accepted by many scholars, within both cultural studies and mainstream history. ${ }^{41}$ Much scholarly work, notably Michael Hechter's "internal colonialism” thesis, has been erected with the assistance of these foundations. ${ }^{42}$ But Curtis reenacts late nineteenth-century party political positions in a further important particular. This is the political influence that British anti-Irish prejudice is said to have exerted in the home rule debates: the "most crucial question" in these debates, Curtis suggested, was whether or not the native Irish were capable of self-government. ${ }^{43}$ Thus "what really killed Home Rule in 1886 and 1894 was the Anglo-Saxon stereotype." ${ }^{44}$ Implicitly, therefore, it is argued that other objections to home rule raised at the time can be reduced to a "racist" core. In fact, several such objections

${ }^{35}$ E. L. Godkin, “An American View of Ireland," Nineteenth Century 12 (July-December 1882): 175-92, esp. 177, 175 .

36 "Do the English Hate the Irish?" Spectator, no. 2823 (5 August 1882), pp. 1014-15, esp. p. 1014

${ }^{37}$ Roy Foster, "Paddy and Mr. Punch," in Paddy \& Mr. Punch: Connections in Irish and English History (Penguin, 1993), pp. 171-94.

${ }^{38}$ Godkin, "An American View of Ireland," pp. 179-80, 182.

${ }^{39}$ Goldwin Smith, "Mr. Godkin on Ireland," Spectator, no. 2832 (7 October 1882), p. 1285.

${ }^{40}$ Elisabeth Wallace, Goldwin Smith: Victorian Liberal (Toronto, 1957), pp. 95-96; E. L. Godkin, "Mr. Godkin and the Irish Question," Spectator, no. 2836 (4 November 1882), p. 1409; Edwin Lawrence Godkin papers, Houghton Library, Harvard University, bMS Am 1083, 970-1, Smith to Godkin, 10 and 22 October 1882; Alan O'Day, "Home Rule and the Historians," in The Making of Modern Irish History: Revisionism and the Revisionist Controversy, ed. David George Boyce and Alan O'Day (London, 1996), pp. 141-62, esp. p. 159; Curtis, Apes and Angels, pp. xv, xxvii, n. 21.

${ }^{41}$ A recent example of this acceptance can be found in Susan Kingsley Kent's major survey Gender and Power in Britain, 1640-1990 (London, 1999), esp. pp. 212-14, 221. Kent's interpretation of mid-nineteenth-century British-Irish relations is almost entirely dependent on editions of books by Lebow and Curtis well over two decades old by time of publication.

${ }^{42}$ Michael Hechter, Internal Colonialism: The Celtic Fringe in British National Development, 1536-1966 (Berkeley, Calif., 1975), pp. xvi-xvii.

${ }^{43}$ L. P. Curtis, Jr., Anglo-Saxons and Celts: A Study of Anti-Irish Prejudice in Victorian England (Bridgeport, Conn., 1968), p. 4.

${ }^{44}$ Ibid., p. 107. 
should not be directly equated with racism. These included genuine (if misguided) doubts about the compatibility of political liberty and government by Roman Catholics, concern about the fate of nonnationalist minorities in Ireland, fear for the effect of the measure on Britain's imperial and strategic position (especially given the proximity of a home rule Ireland), and the belief that there would be, even with good will on both sides, friction between two separate centers of sovereignty in the Atlantic archipelago. ${ }^{45}$

This sleight of hand is particularly puzzling on account of Curtis's awareness of the existence of anti-Irish "racism" among supporters of home rule, such as the historian Edward Freeman. ${ }^{46}$ Nonetheless, the assumption that anti-Irish prejudice was the "real" source of opposition to home rule would appear to have roots directly in the arguments put forward by supporters of home rule at the time. As Godkin himself told his American readers of the 1886 Home Rule Bill, "A careful examination of the arguments directed against it by Mr. Gladstone's English opponents shows clearly that they all resolve themselves, in the last analysis, into the thesis that the Irish are a peculiar people and unfit for self-government, and that, therefore, no scheme of which they are to have the management will succeed." ${ }^{47}$

This view was consolidated by Lord Salisbury's famous "Hottentot" speech of 15 May 1886, which had a great effect on leading home rulers. ${ }^{48}$ In subsequent debates too, British home rulers, like Curtis, argued that no one could oppose the measure without endorsing "extravagant theories of Irish depravity." ${ }^{49}$ Perhaps most significantly, with the eventual concession of self-government to nationalist Ireland in the Anglo-Irish treaty of 1921, those liberals who had been sympathetic to home rule, such as J. L. Hammond and C. P. Scott of the Manchester Guardian, ignored differences between the treaty and the home rule bills and rapidly laid down the orthodoxy that their advocacy had been vindicated. Efforts to demonstrate that opposition to home rule had all along been dependent on anti-Irish prejudice certainly cohered to this argument. ${ }^{50}$ The long absence of serious scholarly challenge to such assumptions, ${ }^{51}$ and especially their more recent acceptance in scholarship of anti-Irish prejudice, is evidence that even so-called critical scholars are quite capable of siding with the "victors" in some of history's great dramas in a strikingly uncritical fashion. Indeed, notwithstanding his Anglophilia and distinctly ambivalent attitudes to the Irish and to his own Irishness, in view of the long canonical status of the Nation within American historiography, it is tempting

\footnotetext{
${ }^{45}$ J. L. Loughlin, Gladstone, Home Rule and the Ulster Question, 1882-93 (Dublin, 1986).

${ }^{46}$ Curtis, Anglo-Saxons and Celts, pp. 13, 63, 80-83.

${ }^{47}$ [Godkin], "The Proposed Irish Parliament," New York Nation 42, no. 1087 (29 April 1886), pp. 356-57.

${ }^{48}$ Richard Shannon, Gladstone: Heroic Minister, 1865-1898 (London, 1999), pp. 434-35.

${ }^{49}$ Manchester Guardian (12 April 1912), p. 8b-c, (1 May 1912), p. 8b-c.

${ }^{50}$ G. K. Peatling, "New Liberalism, J. L. Hammond and the Irish Problem, 1897-1949," Historical Research 73, no. 180 (February 2000): 48-65.

${ }^{51}$ Andrew Gailey, "Failure and the Making of the New Ireland," in The Revolution in Ireland, 1879-1923, ed. David G. Boyce (Basingstoke, 1988), pp. 47-70, esp. p. 47.
} 
to suggest that Godkin's articulation of this view exerted a direct impression on in turn influential writers such as Curtis. ${ }^{52}$

The procedure of equating experiences and representations of the Irish with those of colonized or subjugated nonwhite groups can thus be criticized for unconsciously reenacting partisan positions adopted during the home rule period and subsequently. More seriously, however, the historical accuracy of arguments that emphasize the political significance of anti-Irish prejudice can be questioned on two further grounds. First, such arguments are overdetermined in that the fact of anti-Irish prejudice alone explains poorly the often complex specific character of representations of the Irish in many British sources. One can conceive of a large number of hypothetical or actual cases in which the fact of "prejudice" against other ethnic groups could equally be cited as a "cause" of the representation of such groups, although such groups were or are represented differently from (whether more or less negatively than) the Irish. To demonstrate the existence of prejudice in the current case thus tells us little about why certain specific ideas were held about the Irish and still less explains the structures of British-Irish political relationships in particular phases. Second, and more critically, arguments advancing the key political role of British anti-Irish prejudice are dependent upon essentially naive conceptions of causality. Those scholars in Irish studies who trace an explanation of the phenomenon of resistance to Irish nationalism in Britain to formations and discourses evincing anti-Irish prejudice fail to assess whether the locations of such formations and discourses could have given them the requisite access to influence over the political process. In fact, as the remainder of this article will demonstrate, it is the political strength of contrary discourses about the Irish in Britain, at least at key conjunctures, which should be emphasized.

Perry Curtis helped to inspire the growing body of research into anti-Irish prejudice with the assumption that political action in British-Irish relations was heavily influenced by what the British "really" felt: "The so-called Irish Question is in need of historians who are willing to dig down beneath the surface of party manifestos and parliamentary debate." ${ }^{53}$ Curtis's aim at this point to recover the "real" history behind a public facade is curiously similar to that adopted by A. B. Cooke and John Vincent in a famous series of interpretations of a similar historical terrain. Cooke and Vincent, however, came to a very different conclusion, suggesting not the salience of anti-Irish prejudice among British unionists but rather that all the "genuine feeling for the Irish" in British circles was to be found among a few leading unionist politicians. ${ }^{54}$ This divergence arises from a shared refusal to interrogate critically the context of the sources surveyed. The writers are convinced that their differing ranges of materials each contains the key to the his-

\footnotetext{
${ }^{52}$ William M. Armstrong, E. L. Godkin: A Biography (Albany, 1978), esp. pp. xviii, 94-97; Edwin Lawrence Godkin miscellaneous personal papers, New York Public Library, Godkin to J. M. Libbey, 23 October 1882.

${ }^{53}$ Curtis, Anglo-Saxons and Celts, pp. 1-8, esp. p. 1.

${ }^{54}$ A. B. Cooke and John Vincent, The Governing Passion: Cabinet Government and Party Politics, 1885-1886 (Brighton, 1974), p. 39; John Vincent, "Gladstone and Ireland," Proceedings of the British Academy 63 (1977): 193-238.
} 
toriographical problem in question, and they fail to understand that the featured private ruminations, political speeches, and/or published writings were subject to refraction and reinterpretation through public debate, shared assumptions, and conventional values before exercising influence on late Victorian politics and government. ${ }^{55}$ Researchers are now generally critical of such weaknesses of Cooke and Vincent's supposedly archive-grubbing myopic approach. ${ }^{56}$ Yet more recent "cultural studies" scholarship is often reliant on sources still more distant from the political decision-making process. Too much can certainly be read into the tortuous machinations of politicians in $1885-86$, but such a narrative surely yields a closer insight into the attitudes of "the British ruling class" to the Irish and to "dangerous currents in European thought" than the much-quoted writings of Frederick Engels. ${ }^{57}$ Meanwhile, it is doubtful if very much at all should be read into the midcentury letters of novelists and social critics such as Charles Kingsley. Yet scholarly arguments about anti-Irish racism are frequently excessively dependent on sources such as the latter, and on few examples of these. ${ }^{58}$

This is not to suggest that no instances of the racialization of the Irish occurred or that they were insignificant. As historians have correctly noted, striking examples of Victorian pseudoscientific research concerned themselves with "proving" that the supposed depravity of "the Irish" was racially determined. ${ }^{59}$ For some historians, the researchers responsible, such as John Beddoe, had an influence on political debates such as the 1880s home rule question, via popularizers or otherwise. Lebow specifically cites an anonymous 1882 pamphlet, What Science Is Saying about Ireland, which argued that the Irish were fitted to "the same political institutions as England" no more than would be a hypothetical island inhabited by "negroes" located off the coast of Britain. ${ }^{60}$ This pamphlet, Lebow suggests, forms critical evidence that the image of the Irish in Britain "was much closer to their image of the African native than it was to their image of Englishmen or other Europeans. ${ }^{" 61}$ Curtis and other observers have also noted that another high point in the projection of negative racialized images of the Irish in Britain coincided with outbreaks of Fenianism in the 1860s. In this context, de Nie argues that the Irish were the most important out-group against which the British "consistently" measured themselves: an Irish racial identity was constructed containing facets "which were always the mirror opposite of those that defined English values." ${ }^{62}$

\footnotetext{
${ }^{55}$ Stefan Collini, Public Moralists: Political Thought and Intellectual Life in Victorian Britain, 1850-1930 (Oxford, 1991); G. K. Peatling, British Opinion and Irish Self-Government, 1865-1925: From Unionism to Liberal Commonwealth (Dublin, 2001), pp. 1-7.

${ }^{56}$ David Cannadine, "British History: Past, Present and Future," Past and Present, no. 116 (August 1987): 169-191, esp. 189

${ }^{57}$ Philip Cohen, "The Perversions of Inheritance," p. 74; Hickman, "Alternative Historiographies of the Irish in Britain," p. 245.

${ }^{58}$ Howe, Ireland and Empire, p. 129.

${ }^{59}$ Nancy Stepan, The Idea of Race in Science: Great Britain, 1800-1960 (Hamden, Conn.: Archon Books, 1982), p. 96; Curtis, Apes and Angels, pp. 19-20; Curtis, Anglo-Saxons and Celts, p. 71.

${ }^{60}$ What Science Is Saying about Ireland, 2d ed. (Kingston-upon-Hull, 1882). This pamphlet appeared in two editions, in 1881 and 1882, and may have been written by the M.P. Henry Chaplin.

${ }^{61}$ Ned Lebow, "British Historians and Irish History," Éire-Ireland 8, no. 4 (Winter 1973): 3-38, esp. 37-38.

${ }^{62}$ Michael de Nie, "AA Medley Mob of Irish-American Plotters and Irish Dupes': The British Press and Transatlantic Fenianism," Journal of British Studies 40, no. 2 (April 2001): 213-40, esp. 234-35, 214.
} 
Catherine Hall argues that "in the imagined nation as it was reconstituted [during the reform debates of] 1867, 'Paddy', the racialized Irishman, stood as a potent 'other' to the respectable Englishman, who had proved his worth and deserved a vote." 63

Such depictions of the racialization of the Irish and its political and cultural consequences, however, seem crude and exaggerated; several important influences delimited the political power of anti-Irish prejudice, "scientific" or otherwise. Pseudoscientific Victorian debate about the position of the Irish or groups in Irish society in racial hierarchies cannot simply be reduced to instances of English racism. ${ }^{64}$ In political terms, there was a project in Britain, formulated during the high points of negative representation of the Irish, to reduce or remove the representation in the Westminster Parliament of constituencies likely to elect Irish nationalists. Sometimes this proposal was justified with decontextualized reference to the fall in Ireland's population since the famine and at other times merely with reference to the nature of the representatives that nationalist Ireland was returning to Westminster. The advocates of such a measure included several of the suspects commonly listed in iterations of British anti-Irish prejudice, such as Goldwin Smith. ${ }^{65}$ Yet even Goldwin Smith rejected the fulminations of What Science Is Saying about Ireland, ${ }^{66}$ and Smith was himself hardly regarded as reliable by most of his British contemporaries. Few major political actors thus pursued Smith's project of removing Ireland's entitlement to parliamentary representation under the Union, an entitlement that had few analogies in the treatment of majority nonwhite locations in the British Empire in this period and that meant that Ireland within the Union already in a sense had "self-government" and rarely questioned access to "the same political institutions as England." ${ }^{67}$ Indeed, the parliamentary representation of Irish nationalism was in fact effectively increased at a crucial stage through the enfranchisement of new voters likely to support Parnell's Irish Parliamentary Party through the parliamentary reform of 1884-85. This concrete evidence shows not only that the Irish cannot "always" have been viewed as "the mirror opposite" in racial terms of the English but also that, while the Irish were racialized, such representations were far from entailing the disenfranchisement of "the Irishman."

In this sense, mainstream views of the Irish in Britain were close not to Smith's but to Godkin's, who equated the Irish not with blacks, but with whites, in the American South. British and Irish unionists, in turn, were for Godkin not the equivalent of the Southern whites, but of those antebellum Northern advocates

\footnotetext{
${ }^{63}$ Catherine Hall, "The Nation Within and Without," in Defining the Victorian Nation: Class, Race, Gender and the Reform Act of 1867, by Catherine Hall, Keith McClelland, and Jane Rendall (Cambridge, 2000), pp. 179-233, esp. p. 220. Also see Catherine Hall, Civilising Subjects: Metropole and Colony in the English Imagination, 1830-1867 (Chicago: University of Chicago Press, 2002)

${ }^{64}$ Greta Jones, "Contested Territories: Alfred Cort Haddon, Progressive Evolutionism and Ireland," History of European Ideas 24 (1998): 195-211.

${ }^{65}$ Goldwin Smith, "The Administration of Ireland," Contemporary Review 48 (July-December 1885): 1-9, esp. 6-7; J. A. Froude, "Ireland," Nineteenth Century 8 (September 1880): 341-69; James Higgin, The Irish Government Difficulty Considered as a Race Question (Manchester, 1867).

${ }^{66}$ Goldwin Smith, "What Science Is Saying about Ireland," Pall Mall Gazette (25 March 1882), p. 2 .

${ }^{67}$ G. K. Peatling, "Victorian Imperial Theorist? Goldwin Smith and Ireland," in Victoria's Ireland? Irishness and Britishness, 1837-1901, ed. Peter Gray (Dublin, 2004), pp. 27-36.
} 
of radical reconstruction in the American South, to whom the Southern white was unfit for political liberty and "an irreclaimable person" whose thoughts centered on "murder and massacre and deception." "There is no kind of politicians more familiar to the student of history" than such Northern radicals, Godkin suggested. "In Ireland he is the Orangeman; in Italy he used to be the Austrian; in Turkey he is the Turk; in England he was the old Tory, who thought the best remedy for Irish or colonial discontents was 'a $\mathrm{d}-\mathrm{d}$ good thrashing, sir." ${ }^{68}$ Self-government in Ireland thus recommended itself to Godkin as a coproject not of the emancipation of Southern slaves, and definitely not of radical policies to improve the condition of emancipated African Americans, but rather of the maintenance of modified white supremacy. ${ }^{69}$

Curtis and Lebow are correct to detect changes over time in images of the Irish in Britain and to suggest that negative racial representations of the Irish were more potent around the time of the famine and in the mid-nineteenth century than in later periods. ${ }^{70}$ But this has not stopped Curtis and other scholars from trying to argue that anti-Irish prejudice in Britain was politically important in later periods and indeed on into the 1920s. ${ }^{71}$ In a recent article, R. M. Douglas traces examples of racial theory about the Irish in Britain in the two decades after the 1921 treaty. ${ }^{72}$ But Douglas also instances practically no legislative consequence of this reformulated prejudice. ${ }^{73}$ In fact, far from Britain becoming unwelcoming to Irish immigrants in this period, it became a relatively more popular destination, as the United States became less attractive and more restricted. ${ }^{74}$ Among Douglas's examples of interwar racialization of the Irish, the diaries of Leopold Amery when secretary of state for dominion affairs in 1927 seem a plausible example of the political importance of such discourses. ${ }^{75}$ In fact, Douglas might have cited a still more striking letter that Amery wrote in the summer of 1921 to Prime Minister Lloyd George's secretary when Amery was parliamentary secretary to the Admiralty. At a moment when the then truce in the war of independence seemed fragile, with Lloyd George unwilling to accept Dáil President Eamon de Valera's assertion of full and independent Irish nationhood, in a moment of obvious irritation, Amery suggested: "There never was in history an Irish 'nation' in any political sense." Amery added that there was "no Irish race," the ethnic content of the Irish population being the same as Britain's except for a strain of "Celtic cavemen—a gorilla

${ }^{68}$ [Godkin], "Some Questions for the President's Opponents," New York Nation 24, no. 615 (12 April 1877), p. 216.

${ }^{69}$ E. L. Godkin, "American Home Rule," in Handbook of Home Rule, ed. James Bryce, $2 \mathrm{~d}$ ed. (London, 1887), pp. 1-23. Such instances seem to problematize attempts to draw close associations between support of the North in the American Civil War and subsequent advocacy of reform in a British-American context. See Hugh Dubrulle, “We Are Threatened with . . . Anarchy and Ruin': Fear of Americanization and the Emergence of an Anglo-Saxon Confederacy during the American Civil War," Albion 33, no. 4 (Winter 2001): 583-613.

${ }^{70}$ Curtis, Anglo-Saxons and Celts, pp. 106-7.

${ }^{71}$ Curtis, Apes and Angels, p. 115.

${ }^{72}$ R. M. Douglas, "Anglo-Saxons and the Attacotti: The Racialization of Irishness in Britain between the Wars," Ethnic and Racial Studies 25, no. 1 (January 2002): 40-63, esp. 57.

${ }^{73}$ Ibid., pp. 52-53.

${ }^{74}$ Tracey Connolly, "Emigration from Ireland to Britain during the Second World War," in The Irish Diaspora, ed. Andy Bielenberg (Harlow, 2000), pp. 51-64.

${ }^{75}$ Douglas, "Anglo-Saxons and the Attacotti," p. 44. 
like creature . . cowardly \& murderous. What really exists in Ireland is not a race or a nation, but a poisonous tradition of hatred . . . crystallised by the accursed Church of Rome, \& [deriving] some slight element of justification . . . from repressive laws \& selfish Cobdenism." Parts of this passage certainly evince a racialization of the Irish, although simultaneously in tension with Amery's suggestion that the Irish were not a race. Significantly however, Amery continued, "But this outburst is irrelevant to my real point which is a fear lest the need for a campaign all out over the Irish business may summon us all back post haste."76 Amery was to make no serious effort at this time to prevent the grant of political autonomy to nationalist Ireland, confining such "outbursts" to his diaries and letters to friends. Indeed, Amery's official relations with the leaders of the new Irish Free State would be (excepting a few difficulties) cordial, and Amery personally favored, under certain conditions, a united Ireland. ${ }^{77}$ The political power of negative racial stereotypes of the Irish was sharply limited.

A reading of Erskine Childers's The Framework of Home Rule (1911) greatly assists attempts to understand and contextualize such limitations. Childers was an imperialist, but he was half-Irish on his mother's side and a supporter of home rule affiliated to the British Liberal party, until he joined Sinn Féin and became a republican after the First World War. ${ }^{78}$ In 1911 Childers advocated a grant of a measure of self-government to Ireland similar to that then effective in the British colonies of white settlement. At this conjuncture this was a seductive and soundly imperialist argument to many British ears owing to the perceived recent success of an analogous measure in South Africa. Childers believed that the British Empire had been a beneficent development everywhere, with Ireland the lone exception solely on account of Britain's failure to apply there the policy of separate selfgovernment effective in the colonies of white settlement. ${ }^{79}$ This omission was due in turn to the power of anti-Irish prejudice in British society: "The Anglo-Irish Union was created and has ever since been justified by a systematic defamation of Irish character." ${ }^{80}$ Like Lebow, Childers charted "that intense national antipathy felt by the English for the Irish race which has darkened all subsequent history" as beginning in the twelfth century. ${ }^{81}$

What is most interesting about Childers's argument, however, is its overt basis in the perceived "elementary principles of governing white men": ${ }^{82}$ the Irish were considered worthy of self-government in Childers's pages precisely because they were perceived to be a white race. Childers asserted, "No white community of pride and spirit would willingly tolerate the grotesque form of Crown Colony administration, founded on force, and now tempered by a kind of paternal State Socialism under which Ireland lives to-day." ${ }^{" 83}$ Implicitly, therefore, such a system

\footnotetext{
${ }^{76}$ Baron Altrincham (Edward Grigg) papers (microfilm copies), Bodleian Library, Oxford, MSS Films 999 (roll no.1): Amery to Grigg, 28 August 1921.

${ }^{77}$ Peatling, British Opinion and Irish Self-Government, pp. 163-64.

${ }^{78}$ Jim Ring, Erskine Childers (London, 1996); Tom Cox, Damned Englishman: A Study of Erskine Childers, 1870-1922 (Hicksville, N.Y., 1975).

${ }^{79}$ Erskine Childers, The Framework of Home Rule (London, 1912), pp. 152, 144-45.

${ }^{80}$ Ibid., p. xv.

${ }^{81}$ Ibid., p. 7; Lebow, "British Historians and Irish History," pp. 5-6.

${ }^{82}$ Childers, The Framework of Home Rule, p. 77.

${ }^{83}$ Ibid., p. 144.
} 
of government would be appropriate for a nonwhite people. Childers's comments on the comparison between the experiences of Native Americans and the native Irish-a comparison in which Gibbons emphasizes similarities-are particularly revealing: "In America and Ireland the Colonies were bi-racial, with this allimportant distinction, that in America the native race was coloured, savage, heathen, nomadic, incapable of fusion with the whites, and, in relation to the almost illimitable territory colonized, not numerous; while in Ireland the native race was white, civilized, Christian, numerous. . . . The parallel, then, in this respect, is slight, and becomes insignificant, except in regard to the similarity of the mental attitude of the colonists towards Indians and Irish respectively." 84

In other words, the prejudices of the conquering groups toward the Irish and the Native Americans were similar; however, such prejudice toward Native Americans was directed toward a "coloured, savage, heathen, nomadic" people and thus was, presumably, to be considered significantly more justifiable. Similarly, in comparing the postconquest land settlement in Ireland and slavery in Carolina, Childers suggested that the former was the more demoralizing because the Irish were racially more similar to their subjugators: "In Ireland the ethnological difference was small; the artificial cleavage and deterioration great in inverse proportion." ${ }^{" 85}$ It was emphatically on a level with white settlers in locations such as South Africa, Canada, the United States, and Australia that Childers wished to place the Irish, not with aboriginal, enslaved or subjugated nonwhite populations. The latter featured singularly little in Childers's argument and at times disappeared altogether. When Childers suggested that "anywhere outside Ireland," "men would say that selfgovernment was the best road to the reform of a bad land system," it was not to suggest self-government in parts of the British Empire that had a nonwhite majority. Childers merely believed that such a suggestion would so obviously not be entertained that overt rejection was hardly necessary. ${ }^{86}$

Several contemporary reviews of Childers's book showed an awareness of the role that racialization of the Irish as white played in his argument. The Spectator accepted Childers's proposition that self-government "is the cure for all ills in every part of the Empire which is inhabited by a predominant population of European birth, and is by geographical situation a natural self-containing area of administration," adding, however, that Ireland was not such a "natural" area, as it was too close to Britain. ${ }^{87}$ A review in the unionist Glasgow Herald, commenting on Childers's prediction of the gains that would accrue to Ireland from selfgovernment, briefly noted that "Indian patriots will be inclined to wonder at the confinement of these benefits of freedom to the "white races." necessarily mean that the Herald believed that the political systems in Ireland and India should be identical. The Belfast-born, Protestant Irish nationalist Robert Lynd meanwhile praised Childers's book, arguing that "Mr. Childers's logic, as he develops his case for self-government, is inescapable, if you admit, as an appreciable minority even of unionists will, that Ireland is a country inhabited by

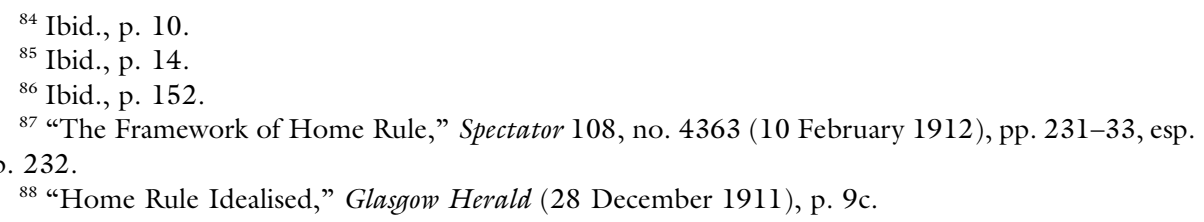


white men." Childers had appreciated, Lynd suggested, that the "case for Home Rule rests on the recognition of the fact that the essential Irish character in its balance of good and evil is very much the same as the character of the other white races." 89 Once again, a contemporary sympathizer with Irish nationalism at once accused unionists of professing the same prejudice against the Irish as against nonwhite groups and met this alleged prejudice with an emphatic assertion that the Irish were white (and, in this case, gendered male), without any attempt to change prejudice against nonwhite races or to suggest that the latter was unjustified. Even Lynd, a humane and ardent anti-imperialist who was genuinely perturbed by Childers's imperialism, felt such a dichotomy between "good Europeans" and "wild animals" to be unproblematic. ${ }^{90}$ The Irish were clearly to be placed in the former category, nonwhite subject peoples of the British Empire, presumably, largely in the latter.

It might be argued that Childers was not representative or influential and is just a single example, much as the opposite argument that the Irish were placed on a position in racial hierarchies close to that of nonwhite groups utilizes few examples. But the nature and historical significance of these examples are very different. The bases on which Childers could be deemed exceptional, and racism or imperialism in such instances dismissed as not "truly Irish" in the way that antiracism is sometimes asserted to be, are unconvincing. While writers such as Walter and Hickman deny the typicality of Irish individuals such as Childers whose role within the British Empire was more as colonizers than as colonized, ${ }^{91}$ much work has elucidated historical levels of complicity and participation in British imperialism from Irish sources. ${ }^{92}$ To argue that Childers should be dismissed because he was a hybrid Anglo-Irishman is to reenact certain essentialist contemporary discourses surrounding him. ${ }^{93}$ Childers's argument was more obviously politically significant at the time than the litany of contemporary instances of solidarity between Irish nationalists and nonwhite victims of imperialism commonly cited.${ }^{94}$ Childers's book made a major impact in Britain and was widely praised, especially in British Liberal circles, ${ }^{95}$ but also even by critics such as Amery who considered it one of the best statements of the case for home rule. ${ }^{96}$ Correspondingly, arguments cognate to Childers's continued to surface in the British radical press until the 1921 treaty. In 1912, the Daily News argued, "Equality of citizenship and self-government

\footnotetext{
${ }^{89}$ Robert Lynd, “A Book of the Day," Daily News (12 December 1911), p. 3b.

${ }^{90}$ Robert Lynd, "If the Germans Conquered England," in If the Germans Conquered England, and Other Essays (Dublin, 1917), pp. 1-8, esp. p. 3, and "A Book of the Day," p. 3b.

${ }^{91}$ Mary J. Hickman and Bronwen Walter, "Racializing the Irish in England: Gender, Class and Ethnicity," in Reclaiming Gender: Transgressive Identities in Modern Ireland, ed. Marilyn Cohen and Nancy J. Curtin (New York, 1999), pp. 267-92, esp. p. 268.

${ }^{92}$ Keith Jeffery, ed., "An Irish Empire?” Aspects of Ireland and the British Empire (Manchester, 1996); Donald Harman Akenson, If the Irish Ran the World: Montserrat, 1630-1730 (Montreal, 1997); Hiram Morgan, "An Unwelcome Heritage: Ireland's Role in British Empire-building," History of European Ideas 9 (1994): 619-25.

${ }^{93}$ Ring, Erskine Childers, pp. 272-80.

${ }^{94}$ Gibbons, "The Global Cure?” pp. 100-103.

95 "The Basis of Home Rule," Daily News (1 February 1912), p. 4b-c.

${ }^{96}$ Hansard's Parliamentary Debates, 5th ser., vol. 46, cols. 1218-27 (8 January 1913); Spectator 108, no. 4363 (10 February 1912), p. 231. Reviews of The Framework of Home Rule are collated in the Robert Erskine Childers papers, Trinity College Dublin Library, 7901.
} 
may claim to be the specifically English contribution to the art of government, applied everywhere, and everywhere with success, except to Ireland with the miserable consequence which all candid men or men with eyes to see admit." ${ }^{\prime 97}$ Again, such analysis simply ignored parts of the British Empire peopled by nonwhites. In an attack on the Treaty of Versailles in 1919, J. L. Hammond argued that "the most glaring case of refusing the right of self-determination to a white people is to be found in our treatment of Ireland." ${ }^{98}$ Hammond's implication that the refusal of self-determination to nonwhite peoples was significantly less "glaring" renders his later role in exaggerating the grounding of British resistance to Irish home rule in prejudice somewhat ironic.

Childers's argument for colonial home rule (or, as it became, "dominion" home rule) and his later advocacy of a republic were both unusually early and specific iterations of the types of constitutional settlement that would eventually be effective within at least twenty-six counties of Ireland. In other words, Childers's forms of racialization of the Irish and of other groups, not any opposite assumptions, were cognate to the most important political changes occurring in a key conjuncture for the future of British-Irish relations. Some scholars argue that these settlements were either the product of a military victory by nationalist Ireland over the British in the war of independence, ${ }^{99}$ or conditioned by the continued effective political and economic control of Ireland by Britain. But the evidence suggests that, at least concurrently, propagandistic discourses such as Childers's, incorporating the emphatic assertion of the feasibility of separate self-government for a racialized white people such as the nationalist Irish, were widely and importantly accepted within the British political system. Manifestations of the denial of the whiteness of the Irish in the field of cultural representation, while endlessly inspected in current scholarly literature, were by comparison never so strong and had become politically feeble by the crucially important Edwardian period.

Scholars are correct to observe that racial barriers can be erected and manipulated for reactionary purposes. Construction, flexibility, and the risk of pernicious political consequences, however, are relevant to an analysis not only of "race" as a formation but also of responses to its invention by "radical" interpreters. Whereas "liberal" critique of British establishment anti-Irish "racism" today involves the insistence that for certain purposes it is useful to think of the Irish as if they were black, such critics' early twentieth-century predecessors met similar prejudice by identifying the Irish not only as a white race but also to be equated with white (and occasionally genocidal) colonizers and settlers. By the 1910s and 1920sperhaps the decisive conjuncture for the future of British-Irish political relationsthis insistence, and the concomitant perceived distance between the conditions and entitlements of the Irish and of the nonwhite peoples of the British Empire, were the dominant influences. An Irish nationalist movement that prioritized the goal of independence would have gained little at this time from identification with

\footnotetext{
97 "The Progress of Home Rule," Daily News (2 March 1912), p. 4b-c.

${ }^{98}$ J. L. Hammond, "The Catastrophe of Paris," Nation 25, no. 10 (7 June 1919), p. 288

${ }^{99}$ William H. Kautt, The Anglo-Irish War, 1916-1921: A People's War (Westport, Conn., 1999).
} 
the nonwhite world, especially since, contrary to the implications of theorists of anti-Irish racism and of postcolonialism, for the vast majority in Britain and Ireland, nationalist or unionist, a self-governing Ireland was at this time more easy to conceive of than self-government in almost any predominantly nonwhite part of the British Empire. Thus, by the 1920s, the Free State achieved equal representation at imperial conferences with other dominion governments at the same time that India was in part represented by co-opted maharajahs and most of the other nonwhite peoples of the empire were without equivalent representation. ${ }^{100}$ Only with the formal independence of third-world nations and the rise of postcolonial scholarship did the implication that the position of the Irish could be equated with nonwhites, and enthusiasm about Ireland's trail-blazing decolonization, gain political or academic credence. The willingness of many active in that decolonization to assign Ireland a seat in the interwar white racialized high-imperial council should be a source of discomfort to any postcolonial scholar prepared to observe it.

It is not reasonable to conceptualize such late nineteenth- and early twentiethcentury representations of the Irish as white as a desertion by Irish nationalists of their nonwhite fellow victims of colonialism. It is invidious to try to suggest that Irish nationalism, the Irish republic, or the Irish people have particularly xenophobic, or in David Trimble's terms, "pathetic sectarian, mono-ethnic, monocultural," propensities. ${ }^{101}$ While sometimes fertilizing a lazy justification of the political aims of Ulster unionists, ${ }^{102}$ this reading misses the spatial and chronological specificity of such moments, as well as the substantial difficulties that any alternative self-representation from solely Irish sources would have encountered. Nonetheless, to depict a converse process of identification between the Irish and nonwhite former or current victims of colonialism or racism as more authentic is to overlook the specificity of conjunctures when such an identification appeared or appears mutually beneficial, and, from a political point of view, it may also be disastrously complacent. Empathy in such circumstances in fact requires a difficult self-critical process of imagination and analysis, for which the mere fact of ethnic background offers no qualification. Politically convenient, historically challenged narratives offer no quick fix to the problem of racism. Processes of racialization remain a very important focus for historical analysis, but such research should not be compromised by a failure to ask fundamental and historical questions about the representativeness and influence of the favored sources.

\footnotetext{
${ }^{100}$ D. W. Harkness, The Restless Dominion: The Irish Free State and the British Commonwealth of Nations, 1921-31 (London, 1969).

${ }^{101}$ See Henry McDonald, “Anger over Trimble's Irish Insult,” Observer (10 March 2002), http:// www.guardian.co.uk/Northern_Ireland/Story/0,2763,665110,00.html.

${ }^{102}$ Arthur Aughey, Under Siege: Ulster Unionism and the Anglo-Irish Agreement (Belfast, 1989), pp. 28, 207-8: Richard English, "The Same People with Different Relatives? Modern Scholarship, Unionists and the Irish Nation," in Unionism in Modern Ireland: New Perspectives on Politics and Culture, ed. Richard English and Graham Walker (Basingstoke, 1996), pp. 220-35, esp. p. 230.
} 